\title{
THE DELIMITATION OF URBAN HINTERLANDS BASED ON TRANSPORT FLOWS: A CASE STUDY OF REGIONAL CAPITALS IN THE CZECH REPUBLIC
}

\author{
Stanislav KRAFT, Marián HALÁS, Michal VANČURA
}

\begin{abstract}
The delimitation of the urban hinterlands of the most important settlement centres in the Czech Republic, based on transportation flows, is presented in this paper. Transport flows are a very good indicator of complex spatial relations. Therefore, one can hypothesize that the delimited transport hinterlands are strongly associated with other types of urban hinterlands (e.g. commuting hinterlands). Transport regions of the Czech regional capitals are defined in the empirical section of this paper. These transport regions, supra-nodal territorial units of the Czech transport system, identify the main transport relations within the Czech road network and define the hinterlands of the main settlement centres. The metropolitan regions defined by transport relations are compared with regions of the Czech Republic based on commuting flows. There is a high concordance between the two regional delimitations.
\end{abstract}

\section{Shrnutí}

\section{Vymezení zázemí měst na základě dopravních toků: Případová studie regionálních center České republiky}

Hlavním cílem př́spěvku je vymezení zázemí nejuýznamnějších středisek osídlení České republiky založené na dopravních tocích. Dopravní vazby v tomto kontextu predstavují významný indikátor komplexních prostorových vazeb. Lze proto predpokládat, že dopravní zázemí hlavních středisek osídlení jsou ve velké asociaci s ostatními ukazateli použivanými pro vymezování zázemí měst. V analytické části jsou proto vymezena dopravní zázemí krajských měst České republiky. Ty jsou definovány jako nadnodální teritoriální jednotky českého dopravního systému, které identifikuji hlavní dopravní vazby v silniční síti České republiky. V dalši části jsou proto vymezené dopravní regiony srovnávány s metropolitními regiony vymezenými na základě dojiżd’kových vazeb.

Key words: transport system, spatial organization, transport regions, transport flows, commuting to work, Czech Republic

\section{Introduction}

Transport is an important sector of human activity, connected with the daily rhythms of a society. Especially in developed countries, society today can be termed highly mobile and, to a certain degree, dependent on transport. Because transport processes take place within specific geographical conditions, they undoubtedly have many spatial causes and impacts. Moreover, transport has affected the spatial deployment of many socioeconomic activities, and it was therefore often considered by geographers as a key concept of spatial organization in the 1960s and 1970s (Wheeler, Muller, 1986). The study of spatial interactions defined by Ullman (1980) can be provided as an example. The meaning of this concept is the fact that the intensity of spatial interactions indicates the mutual inter-dependence of geographical locations, thus serving as a measure of complementary nature of interactions between society and nature. Inter alia, this is why transport became one of the key concepts of human geographical research in the second half of the $20^{\text {th }}$ century (Keeling, 2007).

Transport flows, which represent a indicator of basic spatial interactions, reflect crucial features of spatial organization (for more details, see, e.g. Morrill, 1974, or Haggett, 2001). With respect to the character of transport production and based on the identification of major transport flows in space, one can also identify nodal/functional regions based on the transport intensity connecting individual areas in relation to major centres. This approach is often used as an alternative to the traditionally-defined catchment regions based on commuting to work or for services (for a more detailed discussion, see, e.g. Hůrský, 1978, or Jordan, 1995). In this context, Šlampa (1972) argues that functional regions defined on the basis of transport flows are in fact functional socio-economic regions, as the transport flows in this case serve as a key indicator of nodality and the regional influence of centres. At the same time, a characteristic feature of transport is the fact that it sensitively reacts to changes in socioeconomic conditions, and thereby it is a very good indicator of more general processes describing changes in spatial organization (see e.g. Řehák, 1988).

This paper aims at demonstrating the mutual reciprocity between the spatial organization of the society and transport flows. Transport and commuting flows are used to delimit the urban hinterlands of regional capitals in the Czech Republic, by analyzing the most important of such flows. A strong mutual correlation can be assumed, because commuting flows form a substantial part of the transport flows. Some differences between the delimitation of transport and commuting hinterlands can be expected, however, as different data and methods are used. The wellestablished term "metropolitan region" is used to describe settlements at the level of regional capitals and their wider hinterlands in the Czech Republic (e.g. Hampl, 2005 or Musil, Müller, 2008). Thus, the delimited transport regions 
can be viewed as metropolitan regions based on transport flows among regional capitals and their wider hinterlands.

The tradition of defining the metropolitan systems in the Czech Republic, as for example by Korčák, 1966 or Hampl, 2005, is followed, but different and alternative approaches for delimitation and their mutual comparison are used. As pointed out by Dostál and Hampl (2002), one of the significant features of metropolitan regions as leading units of the settlement system, is their distinctive concentration of population and economic activities and, at the same time, their intensive mutual internal interconnection. Both basic features impose increased demands on transport services in these areas (see the discussion in Horňák, 2006 or Marada, 2008). Therefore, we can presume that the strong integration between metropolitan regions in the Czech Republic relies especially on automobile transport at the present time (the existence of this mutual reciprocity in other countries is pointed out, for example, by Giuliano, 1998; Muller, 2004 or Nuhn, Hesse, 2006).

The empirical sections of this article specify and evaluate the transport hinterlands of the main settlement centres in the Czech Republic, based on prevailing automobile transport flows. Subsequently, these regions are compared with the metropolitan regions defined by using the intensity of commuting flows, which are most often used for defining the metropolitan hinterlands of the settlement centres (e.g. Hampl, 2005).

\section{Theoretical basis: transport, mobility and spatial organization}

The relatively unique nature of transport relations results in their common use in the delimitation of functional regions. Transport relations serve as key indicators for delimiting the regional sphere of influence of settlement centres. Therefore, a decisive factor is the intensity of transport interactions. In approaches commonly used to date, two types of studies can be observed. Firstly, there are studies of a predominantly methodological character, which address the question of the delimitation of functional transport regions. They deal in particular with questions of the nature and spatial patterns of transport relations as a key element of spatial organization (Godlund, 1956; Green, 1958; for information on the Czech and Slovak environment, see the studies by Hůrský, 1978; Branický, 1988). As examples, the studies applying graph theory to the delimitation of centres and their hinterland (such as Nystuen, Dacey, 1961 or Grubesic et al., 2009) are of interest. To delimit functional regions, these researchers use origin-destination matrices built on the frequency of public transport connections. A second group of studies may be referred to as applications of methods. These studies are primarily focused on the use of transport regionalisation as a basis for the review and formation of territorial and administrative subdivisions or, where appropriate, on the comparison of transport regions and other types of territory regionalisation (Jordan, 1995; Kraft, 2007). Other interesting application studies include those based on the evaluation of associations between the commuting regions and regions of transport (time) accessibility (Hudeček, 2008). It is clear that these two thematic areas of transport region study do not negate each other but complement each other.

The current period of transport system development is characterized by the continuous intensification and spatial reorganization of transport flows, which significantly modify their initial organization. Moreover, this modification strongly corresponds with the transition from the industrial stage of transport / societal systems development into the post-industrial stage (for more details see the studies by Rodrigue et al., 2006 or Hampl, 2005). The post-industrial stage can be characterized by the development of more intensive, organic and integral relations. Some typical significant features include the growing polycentric character and de-concentration of economic activities in urbanized areas (Seidenglanz, 2010; Kunc et al., 2012).

Transport has always represented a significant factor influencing the dynamics of processes related to changes in the spatial organization of society. MacKinnon et al. (2008) state that the above-mentioned relationship of mutual reciprocity between transport and the spatial organization of society is evident in many generally accepted geographical theories, which could be divided into three groups. Location theories are the oldest ones (e.g. Christaller's Central Place Theory), which emphasize the importance of transport costs in the spatial organization of socioeconomic activities. The second group is represented by modernization theories, in which a close relation between the transport system and its impact on changes in the spatial organization of economic activities is declared (e.g. the Vance, Rimmer and Taaffe model - as characterized by Hoyle, Smith, 1998), or models concerned with the issue of the development of towns and metropolitan regions under the impact of the transport network development (as in the famous study: "Transport stages in spatial evolution of the American metropolis" by Muller, 2004). The last group comprises critical theories based on post-positivistic trends in geographical research. One of the most important critical theories related to the role of transport in the spatial organization of society can be considered the concept of temporal-spatial compression and the annihilation of space as discussed in Harvey (1989), or the current trend in geographical, sociological, migration and cultural studies, which is referred to as a "new mobility paradigm" (Sheller, Urry, 2004).

Probably, the results of increased integral transport flows and individual mobility are most evident at a local level, especially in urban regions. Before the development of modern transport systems in the $19^{\text {th }}$ century, most of the pre-industrial cities were characterized by compact built-up areas within walking distance to the city centre (this stage of city development is sometimes referred to as foot cities). In connection with the development of rail transport in the $19^{\text {th }}$ and $20^{\text {th }}$ centuries, work locations were first separated from residence location within the urban environment in the form of a radial spreading of cities along the lines of urban rail transport (tracked cities). With the rapid development of motorization during the second half of the $20^{\text {th }}$ century, a further expansion of city systems took place along with the spatial "spilling" of many urban functions into the surrounding space, i.e. beyond the administrative borders of the city (e.g. Giuliano, 1998).

The spatial expansion of city systems supported by transport is additionally associated with the phenomenon of residential and non-residential suburbanization (for more details, see e.g. Urbánková, Ouředníček, 2006). At a theoretical level, Leinbach (2004) indicates that the above-mentioned processes of spatial de-concentration, suburbanization and increasing motorization in the urban environment transform once typical centripetal and centrifugal movements of inhabitants, goods and information (simple orientation of connections from the hinterland to the city) to a more complicated structure of 
movements within metropolitan regions, which is associated with a growing polycentricity (more complicated lateral and tangential movements: hinterland-city, city-hinterland and hinterland-hinterland). These de-concentration processes in metropolitan regions have been studied especially in developed countries (e.g. Gutiérrez, Palomares, 2007). In this context, Nuhn and Hesse (2006) confirm already-established discussions regarding changes in the spatial structure of transport connections - from a starfish-shaped structure to the more complicated form of a spider-web model.

From this discussion of the relation between the spatial organization of society and transport, we can conclude that transport processes are, with respect to their character, one of the most important determinants and integral processes relating to changes in the spatial organization of society. This also shows that, in assessing the development processes, both of these components must be evaluated in terms of their mutual interactions.

\section{Methods}

This study used data from the latest available Road Transport Census (RTC) of 2010. The RTC database provides detailed current results on the intensities of road transport on almost all roads in the Czech Republic. These results, however, show a number of defects - in particular, they cannot be used to identify the starting and destination points of particular trips, frequency of trips or occupancy of cars. Hence, a method was developed to eliminate these defects - as the intensity on a particular road type is monitored instead of the transport intensity, and the minimum share of the length of relevant roads from the total length of all roads in administrative regions (municipal districts with a delegated municipal office ${ }^{1}$ ), was chosen as an additional criterion, which eliminates especially the administrative regions exposed to transit flows (similar to Kraft and Vančura, 2010).

The research method consists of three steps (Fig. 1). In the first step of the research, the road network sections with the most important transport intensities were defined within the Czech road and motorway networks. For defining the key transport interactions within the Czech road and motorway networks, the upper quartiles $\left(Q_{75}\right.$ : important transport flows) and the upper deciles of values $\left(Q_{90}\right.$ : the

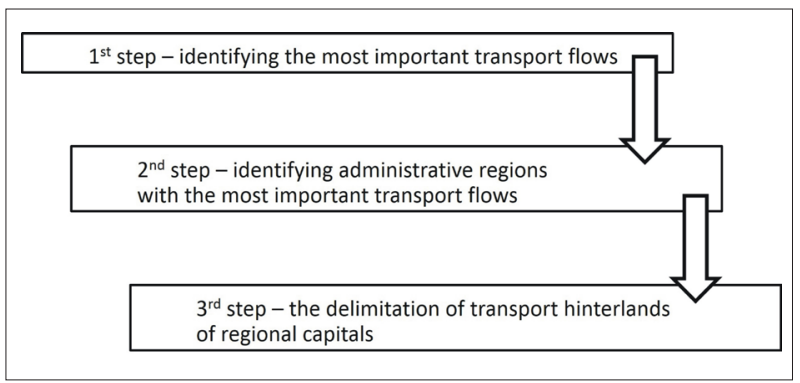

Fig. 1: The methodological procedure used in this study

most important transport flows) of average daily intensity of car transport on particular types of roads were used. This gave rise to the two-level system of key transport relations. Criteria for allocating particular sections of the road network among the most important and important transport flows are shown in Tab. 1. Centres surveyed in this study are assumed according to Hampl's socio-geographical regionalisation of the Czech Republic published in 2001. Hampl (2005) specified 426 centres of at least microregional importance according to their complex size index. The complex size index is an aggregate indicator based on the residential and labour functions of these centres.

Since many disconnected and isolated road sections were created using this methodology, the generated data were generalized at the second step by converting the resulting values (lengths of sections) to the total length of the road network within the administrative regions (ARs). Several variants were tested. An optimum critical value of such a concentration level was taken to be the limit of at least $10 \%$ of the length of relevant sections of the total length of the AR road network. Continuous regions were created, which also appropriately illustrate the main transport flows in the regional capitals' hinterlands. Regions with an active role in generating the most important transport intensity were thus considered those regions whose total length of road network was formed by at least $10 \%$ of sections falling within the important or most important transport intensity. The third step consisted in the final delimitation of transport hinterlands of Czech regional capitals. All regions that play an active role in the process of generating important transport relations and are interconnected with the regional capitals via these connections, were deemed the transport

\begin{tabular}{|l|l|c|}
\hline \multicolumn{1}{|c|}{ Road class category } & & Annual average daily intensity of car transport \\
\hline \multirow{2}{*}{ Motorways } & Important transport flows & $27,325-36,859$ \\
\cline { 2 - 3 } & Most important transport flows & 36,860 and more \\
\hline \multirow{2}{*}{ Speedways } & Important transport flows & $23,036-28,560$ \\
\cline { 2 - 3 } & Most important transport flows & 28,561 and more \\
\hline \multirow{2}{*}{$1^{\text {st }}$ class roads } & Important transport flows & $9,589-13,271$ \\
\cline { 2 - 3 } & Most important transport flows & 13,272 and more \\
\hline \multirow{2}{*}{$2^{\text {nd }}$ class roads } & Important transport flows & $3,488-6,546$ \\
\cline { 2 - 3 } & Most important transport flows & 6,547 and more \\
\hline
\end{tabular}

Tab. 1: Criteria for allocating particular sections of the road network to important and most important transport flows. Source: Authors' calculations

\footnotetext{
${ }^{1}$ Obce s pověřeným obecním úřadem (in Czech) [Municipalities with the accredited municipal authority]. These administrative regions are sometimes referred to as municipalities of the second degree. These regions are the smallest regions executing the fundamental administrative functions (Registry office and construction administration). There are 396 regions in total.
} 
hinterlands. The condition of transport integration of at least two subordinate ARs was used as an additional criterion for the integrity of transport hinterlands.

Similarly, the metropolitan hinterlands of the Czech regional capitals were defined on the basis of daily commutingto-work flows from the 2011 census. Only the commuting interactions, which are usually used for delineating the metropolitan hinterlands in the Czech Republic, based on the one-way or two-way commuting to work flows between the settlement centres (integrated systems of centres - see discussion in Hampl, 2005) are considered. Metropolitan regions of the monitored settlement centres were defined using the AR districts as a share of total commuters to the relevant regional capitals from the total number of employed people (economically active people without the sum of unemployed people) living in the AR. This method, however, brings certain methodological problems. First, it is important to note that the commuting intensity between districts in some regions is very low because of strong agglomerative relations (especially in denser populated regions with the concentration of larger centres). In line with general regionalization procedures (for more details see e.g. Halás et al., 2010), some centres were agglomerated within some metropolitan systems, namely Zlín with Otrokovice, Ostrava with Havířov, Frýdek-Místek with Karviná, Liberec with Jablonec, Ústí nad Labem with Most, Chomutov and Teplice. There are intensive commuting contacts within these agglomerated centres and the results would not be significant enough without their connections.

Another methodological problem is determining the critical level of the share of outbound people from the municipal districts with a delegated municipal office, which may be regarded as significant in creating the commuting relations within the hinterland of regional capitals in the Czech Republic (e.g. Bezák, 2000). According to Toušek et al. (2005), at least $10 \%$ of people commuting to a regional metropolis of all economically active people may be deemed such a critical value. There were also several variants tested. The metropolitan regions based on commuting flows were identified by this criterion. The critical value for the delimitation was ultimately set at $8 \%$ of people commuting to a regional capital out of all employed people in the particular administrative regions. Although this value may be seen as too low, it creates a sufficiently representative and particularly compact area. The number of commuting integrated regions is also very similar to regions integrated by important transport flows (140 regions integrated by commuting flows vs. 137 regions integrated by transport flows).

\section{Results}

\subsection{Transport hinterlands of regional capitals in the Czech Republic}

Based on the above methodological procedures, 137 administrative regions integrated by strong transport relations to metropolitan hinterlands were specified (Fig. 2). These regions are integrated into 12 metropolitan systems (the metropolitan regions of Hradec Králové and Pardubice were consolidated into one unit due to their closeness and intensive transport relations). Unlike previous years, a new transport hinterland for the city of Jihlava was created and in 2010, for the first time, it met the criterion of subsidiarity of at least two AR districts (Třešt and Polná). An essential feature of these regions is especially the occurrence of the groups of centres, which are integrated by the most important transport interactions $\left(Q_{90}\right)$. The very strong transport integration is thus characteristic of the following centre groups: Benešov-Praha (Prague); Zdice-Beroun-Praha; Jílové-Jesenice-Praha; Hluboká nad Vltavou-České Budějovice; Most-Teplice-Ústí n. Labem; Chrudim-Pardubice-Hradec Králové; Tišnov-Kư̌im-Brno; Rosice-Brno; Velká Bystřice-Olomouc; Fryšták-ZlínUherské Hradiště; Ostrava-Frýdek-Místek; Třinec-Bystřice. Other apparent features of the transport hinterlands of regional capitals include an important concentration of transport relations, significant concentration of population

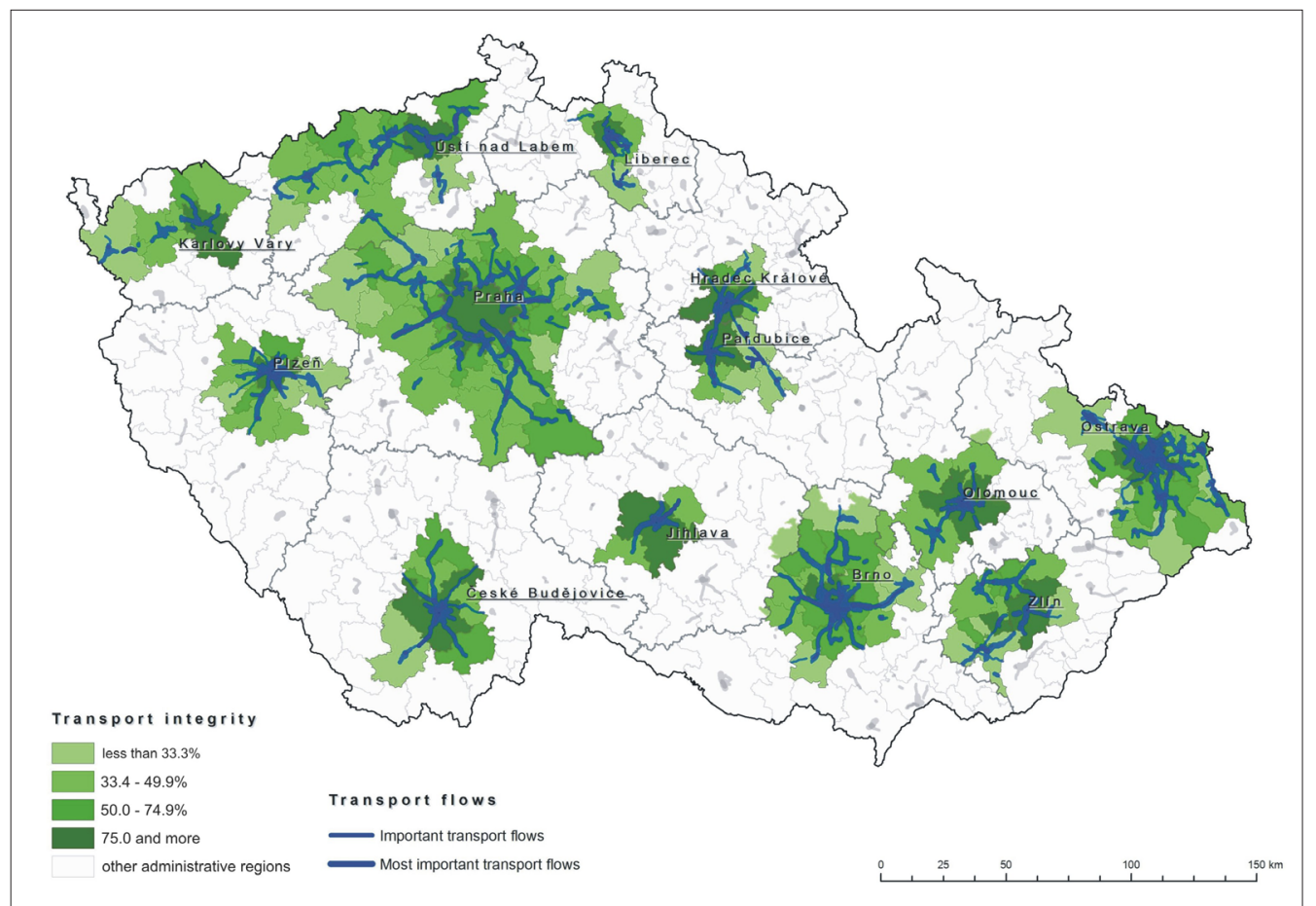

Fig. 2: Transport hinterlands of Czech regional capitals (2010)

Source: CSD 2010, Author's calculations 
and above-average transport infrastructure density in the given territories. Moreover, these regions exhibited the fastest growing motorization in the monitored period (Marada, 2008). Important transport flows were also created outside the metropolitan hinterlands, but they are concentrated mainly in smaller centres only and not integrated into metropolitan systems.

The largest transport hinterland is typical of Prague, which has a singular position within the transport system of the Czech Republic. The position of Prague in the transport and settlement hierarchy is multiplied by creating the largest transport hinterland integrating 44 micro-regional centres and 37 ARs. The central position of Prague is further supported by the radial network of roads and motorways. Other cities with the mono-centric position in their transport hinterlands are České Budějovice, Plzeň, Jihlava, Brno and Olomouc. On the other hand, a considerable polycentric arrangement of transport hinterlands is typical of the regions of Karlovy Vary, Ústí nad Labem, Liberec, Hradec Králové/Pardubice, Zlín and Ostrava. This division strongly corresponds to the nature of the settlement systems of the respective regional settlement centres (for more details see Mulíček, Sýkora, 2011) and is, in some cases, influenced by the character and function of some centres in the transport system. Other important integrated transport systems of settlement centres include the metropolitan hinterland of Ostrava (22 centres integrated by important transport relations), Brno (16 centres) and Ústí nad Labem (15 centres). As to the number of centres, the smallest transport hinterlands systems include Jihlava (2 centres), Liberec (3 centres) and Olomouc (6 centres). Given the different nature, size, function and especially internal differentiation of transport regions, the basic structural properties of such regions were also observed (Tab. 2).

Figure 2 shows transport integrity as an additional feature of transport hinterlands. Transport integrity is characterized as a share of transport intensities crossing the border of an administrative region directed to their regional capital, from the sum of all intensities crossing the border of the appropriate administrative region. It is a relative characteristic of connectivity and a 'self-containment' of transport relations among the regions and their regional capitals. The results of the AR district transport integrity evaluation within transport hinterlands show their mutual internal structuring, in which their spatial proximity is very clearly applied as a key determinant of the intensity of transport interactions with their regional metropolises. Generally, we can apply a hypothetical rule that the regions situated closer to regional metropolises are integrated with stronger transport relations than more distant regions. The apparent development of this relationship and gradation of transport integrity is clear, especially with the larger transport hinterlands (Prague, Brno and Ostrava regions), which integrate more AR districts. Certain disturbances of the distance-decay function in the transport integrity of some regions are usually caused by the above-mentioned problematic nature of the position exposure and inclusion of the transit transport. The shape and deployment of transport networks, which often give rise to certain artificial transport autonomy of some districts, may play a role as well. Despite the foregoing, one can assume that the majority of these districts show a certain degree of relative autonomy of transport connections as well as the organization of relations within the metropolitan systems.

\subsection{The transport and commuting hinterlands of regional capitals in the Czech Republic}

Based on the above theoretical discussions, we can be justified in presuming that the transport hinterlands will be strongly associated with those of metropolitan regions defined according to different relational indicators. The 'unique' position in defining "complex" metropolitan regions is rightly attributed to commuting to work, which represents the most important regional process. On the basis of data on commuting interactions between the centres, the metropolitan regions were defined in the study by Hampl (2005) for example. This author defined a total of 11 metropolitan systems in the Czech Republic, using the districts of municipalities with extended powers (of Czech regional towns, only Jihlava failed to reach the required level of metropolis in 2001). The fact that Hampl applied an additional criterion of distance, by which he divided the

\begin{tabular}{|c|c|c|c|c|}
\hline Rank & Centre & $\begin{array}{l}\text { Number of all } \\
\text { integrated regions }\end{array}$ & Area $\left(\mathrm{km}^{2}\right)$ & $\begin{array}{c}\text { Transport infrastructure } \\
\text { density } \\
\text { (length per } 100 \mathbf{~ k m}^{2} \text { ) }\end{array}$ \\
\hline 1. & Prague & 37 & 7,583 & 41.1 \\
\hline 2. & Ostrava & 17 & 2,925 & 48.5 \\
\hline 3. & Ústí nad Labem & 14 & 2,529 & 46.8 \\
\hline 4. & Brno & 13 & 2,426 & 45.3 \\
\hline 5. & Zlín & 10 & 1,674 & 40.8 \\
\hline 6. & Plzeň & 10 & 1,962 & 49.8 \\
\hline 7. & H. Králové/Pardubice & 9 & 1,859 & 42.0 \\
\hline 8. & Karlovy Vary & 8 & 1,651 & 39.9 \\
\hline 9. & České Budějovice & 7 & 1,901 & 31.1 \\
\hline 10. & Liberec & 5 & 671 & 47.8 \\
\hline 11. & Olomouc & 4 & 1,496 & 48.6 \\
\hline 12. & Jihlava & 3 & 922 & 43.5 \\
\hline
\end{tabular}

Tab. 2: Structural and hierarchical differentiation of transport hinterlands (2010)

Source: CSD 2010, Hampl 2005, Author's calculations 
intensity of two-way commuting flows between the centres to the level of relation interactions of settlement centres, is methodologically questionable. This resulted in certain distortions, such as the Prague metropolitan region as strongly restricted and, on the other hand, the metropolitan territories of Ústí nad Labem and other regions with the occurrence of larger centres located near each other, being inadequately enlarged. A comparison of transport metropolitan regions and metropolitan systems in 2010 , according to Hampl's criteria, is presented in Fig. 3.

What is particularly apparent from the comparison of the two types of metropolitan region definition is their considerable association. A strong concordance manifests itself especially in the regions of Plzeň/Pilsen, Ústí nad Labem and Ostrava. In these cases, it is possible to say that not only commuting but also transport relations are strongly closed within these regions. The above-mentioned issue of the reduced size of the Prague metropolitan hinterland due to the application of the criterion of centre distance, shows principally in the Benešov region, which is in terms of transport a very strongly integrated part of the Prague transport hinterland and also includes strong commuting relations - commuting to work and school (for instance Sýkora, Mulíček, 2009). The strong transport integration with Prague can be similarly seen in the Rakovník, Poděbrady and Dobřís areas, which make up an undeniable transport hinterland of Prague, promoted by good connection to a quality road network providing its advantageous transport accessibility. The most important difference is the alreadynoted creation of the Jihlava metropolitan transport region, which increased its transport competence to the metropolitan level in 2010 .

Notwithstanding certain differences, in a number of cases caused by comparing different AR levels, we can note that the transport metropolitan hinterlands are significantly associated with the metropolitan systems defined on the basis of commuting interactions. This, again, provides significant proof for Šlampa's thesis (1972) on the high complexity of transport relations and their importance in socio-geographical regionalization, as well as Hůrský's thesis (1978) that transport interactions represent a singular indicator of spatial relations between cities and their hinterlands.

Given the difficult evaluation of connections between the transport metropolitan hinterlands and the metropolitan regions defined by Hampl (2005), this study also defined metropolitan regions from the mere intensity of commuting to work. The intensity of commuting to work was expressed as a percentage share of daily commuters working in the regional capitals of the Czech Republic with respect to the number of employed people living in the particular ARs. This procedure shows the connection between the AR districts and the regional metropolises based on the most important regional process, which currently creates functional relations in the regional space. In addition, 11 metropolitan systems were defined in the territory of the Czech Republic, in which $140 \mathrm{ARs}$ (Fig. 4) are integrated.

The definition of metropolitan regions by transport and commuting flows shows a high association, once again. This is somewhat logical because commuting flows constitute a substantial part of transport flows. There is a relatively important similarity in spatial localization. Both types of metropolitan regions are nearly identical as to their area, population and population density. The main structural characteristics of transport and commuting metropolitan regions are summarized in Table 3 . The spatial definition includes moderate disproportions in some marginal parts of metropolitan regions. The transport metropolitan hinterlands also include ARs with relatively strong centres at their edges (e.g. Cheb in the case of Karlovy Vary, Chomutov in the case of Ústí nad Labem, Prostějov in the case of Olomouc, Kroměřǐz and Uherské Hradiště in the case of Zlín or Opava, and Třinec in the case of Ostrava). The size of these centres predetermines their strong transport relations with their regional capitals, but these centres are able to create jobs by themselves, and this is why the commuting flows from these ARs to the metropolitan centres are lower.

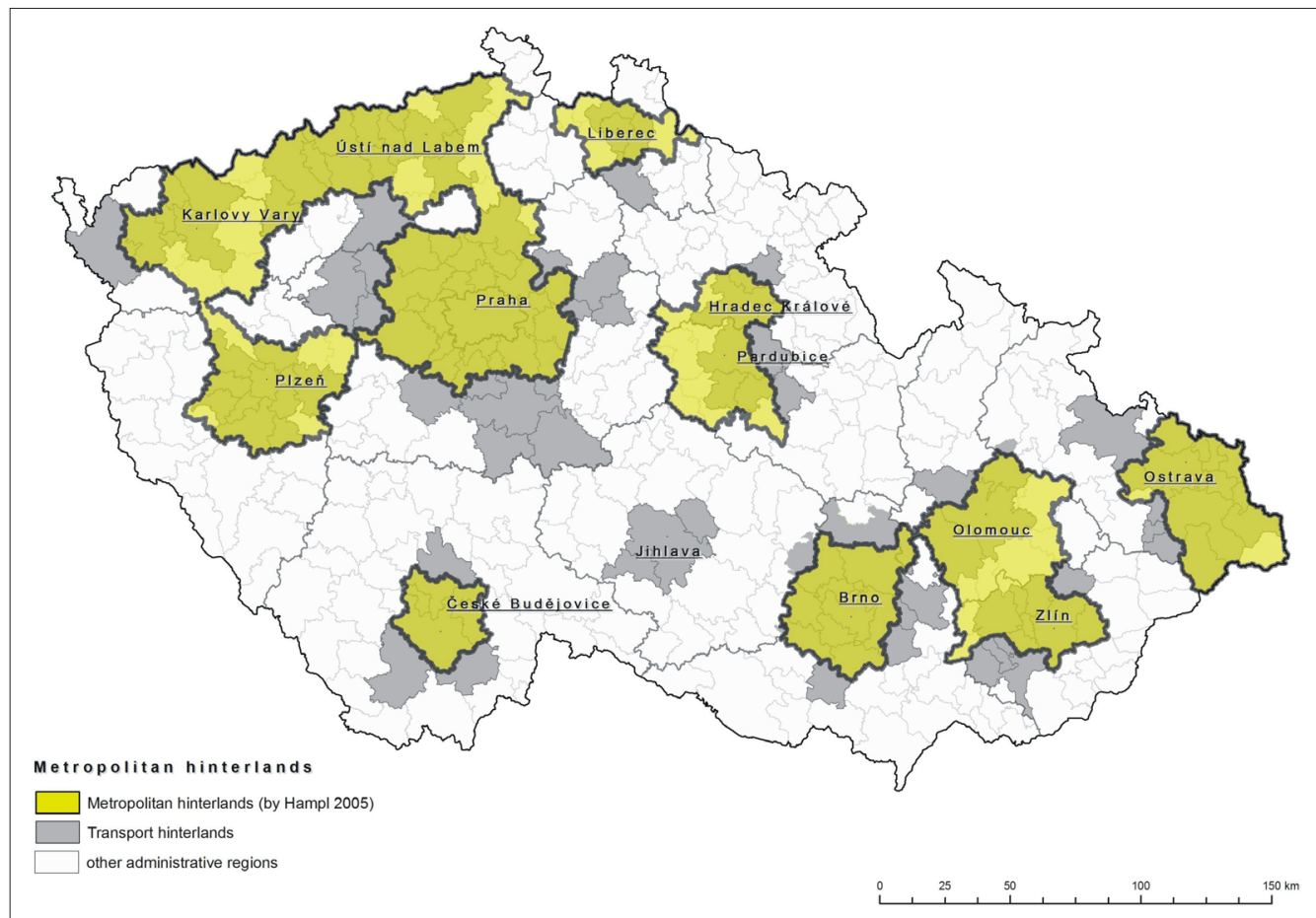

Fig. 3: Comparison of transport hinterlands in the Czech Republic (2010) and metropolitan regions defined by Hampl (2005). Source: CSD 2010, Hampl 2005, Authors' calculations 
The opposite can be seen in the ARs on the outskirts of metropolitan regions with smaller centres (e.g. Frýdlant region, but also the territory between Nechanice and Heřmanův Městec, Všeruby, Hustopeče and Bučovice, etc.). Despite being located within the reach of regional capitals, these regions show a certain degree of peripherality and, with respect to a lower number of their own jobs, they rely on a higher level of commuting to work. Absolute commuting flows from these regions to their regional capitals are quite weaker (predominantly lower than 500 outbound people).

Some differences between the two types of metropolitan region definitions also stem from the course and quality of transport infrastructure (e.g. an AR with an exposed position vs. ARs with a peripheral transport position). In the case of the Prague hinterland, which continuously increases its range of effectiveness, the differences may be partially caused by the different times of the used commuting data and the data from the transport census (e.g. according to Hampl's delimitation). The above facts also imply that the definition of transport metropolitan hinterlands is justified. One of reasons is that the territory is, in defining the transport connections, extended by the ARs with larger centres where it is expected that the connections and interactions of secondary centres with the metropolis may not have to be one-way. The importance of two-way connections of centres within the metropolitan areas is also noted by Hampl (2005). In the case of the definition using commuting, there is a risk that the one-way nodal flows will prevail, as exemplified by a considerable difference in the share of outbound people.

\section{Conclusions}

Based on transport intensity data, we have tried to delimit the transport hinterlands of regional capitals, which can be labelled as transport metropolitan regions. The empirical analyses demonstrated a number of serious factors concerning their objective existence. Some relevant conclusions and facts arise out of the given results focused on both the definition and comparison of metropolitan regions on the basis of the commuting and transport flows. Metropolitan regions are predominantly noted (no matter how they are defined) in the settlement centre hinterland, approximately at the level of regional towns or conurbations. The spatial differentiation of metropolitan regions properly describes the regular coexistence of the dominant situation of Prague, with centres such as Pilsen, České Budějovice, Liberec and other towns at the outer edge of Bohemia, and rather equivalent and more linked relations that are typical for adequate centres in the heart of the Moravian-Silesian

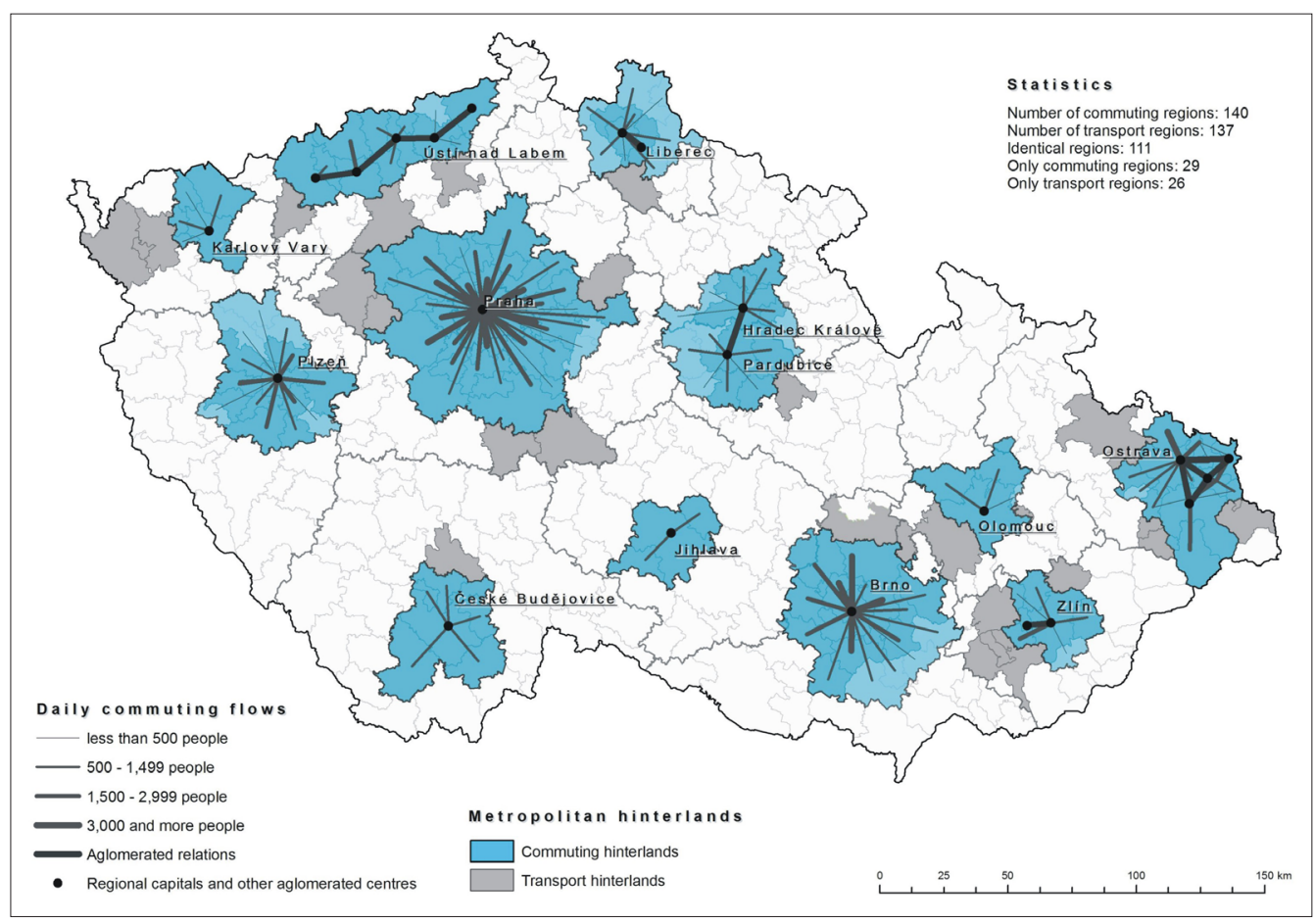

Fig. 4: Comparison of transport hinterlands in the Czech Republic (2010) and commuting metropolitan regions (2011) Source: CSD 2010, Czech Statistical Office 2013, Author's calculations

\begin{tabular}{|l|c|c|}
\hline & Commuting metropolitan regions & Transport metropolitan regions \\
\hline Number of regions & 140 & 137 \\
\hline Total area $\left(\mathrm{km}^{2}\right)$ & 24,812 & 27,599 \\
\hline Share in the population $(\%)$ & 58.3 & 61.5 \\
\hline Average population density & 237.3 & 219.1 \\
\hline Average motorization & 5.1 & 5.8 \\
\hline Average share of outbound people $(\%)$ & 30.8 & 21.7 \\
\hline
\end{tabular}

Tab. 3: Comparison of definitions of transport and commuting metropolitan regions

Source: CSD 2010, Czech Statistical Office 2013, Author's calculations 
Region. A product and, at the same time, a generator of this fact is the strongly concentric transport network in Bohemia and the less regular transport network of Moravia, which is more determined by its relief.

The two examined methods demonstrate a relatively high concordance in defining the metropolitan hinterland of the monitored centres. The transport metropolitan regions can be thus regarded as real and relatively closed socio-economic units created on the basis of automobile transport intensity between the regional metropolises of the Czech Republic and their transport hinterlands. Also, a relatively low influence of the transport exposure of certain AR districts that would affect their allocation to the transport metropolitan regions, as a result of increased share of transit transport was proven, once again.

In some regions, the definition of transport metropolitan regions is affected by the relatively low degree of individual motorization and, on the other hand, by the fairly wellfunctioning system of public transport (see e.g. Chvátal et al., 2011 or Květoň et al., 2012). By analogy, this holds true especially in the regions with well-functioning integrated transport systems, which are able to compete to a certain degree with the fast development of automobile transport. An important role may also be played by the proportion of population using railway and road transport in the metropolitan hinterland for daily commuting to work. The regions located farther from the main metropolises of the Czech Republic usually show lower values of transport/commuting integrity than the regions situated in the hinterlands of these metropolises. Theoretically, the distance-decay effect (i.e. reduction in the intensity of interactions between two locations depending on their mutually increasing distance) can be acknowledged, as well as in the case of transport metropolitan regions. This partially confirms the thesis about peripheral regions located in areas with reduced accessibility to regional centres (most often at the crossing point of regional boundaries), and sometimes even in cases of relatively good accessibility by the main roads.

The delimited transport hinterlands have several applications. They can be used for example as an alternative or additional approach to delimitate urban hinterlands, especially in cases where the commuting flows are complicated or unclear. They can be also used for regional policy and regional planning. One of the most important practical applications is directing the development of transport infrastructure in certain regions or in public transport planning. At present, transport hinterlands reflect the demand for transport in metropolitan regions. The planning of public transport may reflect their existence and adjust the supply of public transport.

\section{Acknowledgement:}

The article was elaborated within the framework of the research grant project "Spatial Dynamics of Transport Relationships in the Settlement System of the Czech Republic", reg. No. 404/12/1035 sponsored by the Czech Science Foundation.

\section{References:}

BEZÁK, A. (2000): Funkčné mestské regiony na Slovensku. Geographia Slovaca Vol. 15, Geografický ústav SAV, Bratislava, 88 p.
BRANICKÝ, M. (1988): Regionálne členenie Slovenskej socialistickej republiky z hladiska dopravy. In: Holeček, M. [ed.]: Současný stav a perspektivy dopravní geografie, Geografický Ústav ČSAV: Brno, p. 104-110.

CHVÁTAL, F., KUCHYŇKA, J., MULÍČEK, O., SEIDENGLANZ, D., STRNADOVÁ, D. (2011): Analýza dopravní obslužnosti v obcích ČR. In: Dopravní obslužnost měst a regionů.

Czech statistical office (2013): Commuting to work and to schools. Census of Population and Housing 2011.

DOSTÁL, P., HAMPL, M. (2002): Metropolitan areas in transformation of regional organisation of the Czech Republic. Acta Universitatis Carolinae - Geographica, No. 2, p. 133-155.

GIULIANO, G. (1998): Urban Travel Patterns. In: Knowles, R., Hoyle, B. [eds.]: Modern Transport Geography, Wiley and sons, Chichester, $374 \mathrm{pp}$.

GODLUND, S. (1956): The Function and Growth of Bus Traffic within the sphere of Urban Influence, Lund, Series in Human Geography, No. 18, 80 pp.

GREEN, F. (1958): Community of Interest Areas - Notes of the Hierarchy of Central Places and Their Hinterlands. Economic Geography, Clark University Concord, New Hampshire, p. 210-226.

GRUBESIC, T. H., MATISZIW, T. C., ZOOK, M. A. (2009): Spatio-temporal fluctuations in the global airport hierarchies. Journal of Transport Geography, Vol. 17, No. 4, p. 264-275.

GUTIERREZ, J., GARCIA-PALOMARES, J. C. (2007): New spatial patterns of mobility within the metropolitan area of Madrid: Towards more complex and dispersed flow networks. Journal of Transport Geography, Vol. 15, p. $18-30$.

HAGGETT, P. (2001): Geography: A Global Synthesis. Prentice Hall, Harlow, 833 p.

HAMPL, M. (2005): Geografická organizace společnosti v České republice: Transformační procesy a jejich obecný kontext. Univerzita Karlova v Praze, Přírodovědecká fakulta, katedra sociální geografie a regionálního rozvoje, Praha, 147 pp.

HARVEY, D. (1989): The Condition of Postmodernity: an enquiry into the origins of cultural change. Blackwell, Cambridge, 378 pp.

HORŇÁK, M. (2006): Identification of Regions of Transport Marginality in Slovakia. In: Komornicki, T., Czapiewski, K. [eds.]: Regional Periphery in Central and Eastern Europe, Europa XXI, 15, IGiPZ PAN, Warszawa, p. 35-41.

HOYLE, B., SMITH, J. (1998): Transport and Development: Conceptual Frameworks. In: Knowles, R., Hoyle, B. [eds.]: Modern Transport Geography, Wiley and sons, Chichester, p. 13-40.

HUDEČEK, T. (2008): Model časové dostupnosti individuální automobilové dopravy. Geografie, Vol. 113, No. 3, p. $140-153$.

HŮRSKÝ, J. (1978): Regionalizace České socialistické republiky na základě spádu osobní hromadné dopravy. Studia Geographica, Vol. 59, Geografický Ústav ČSAV, Brno, 182 pp. 
JORDAN, P. (1995): Functional regions in East-central Europe defined on the basis of the frequency of public bus traffic. Geografický časopis, Vol. 47, No. 1, p. 9-15.

KEELING, D. (2007): Transportation Geography: new directions on well-worn trails. Progress in Human Geography, Vol. 31, No. 2, Sage publications, p. 217-225.

KORČÁK, J. (1966): Vymezení oblastí maximálního zalidnění. Acta Universitatis Carolinae - Geographica, Vol. 1., p. 65-72.

KRAFT, S. (2007): Dopravně geografická regionalizace a hierarchie dopravních středisek Karlovarského kraje. In: Kraft, S. et al. [eds.]: Česká geografie v evropském prostoru, p. 130-138.

KRAFT, S., VANČURA, M. (2010): Transport concentration areas and their relations to spatial organization of the society: A case study of the Czech Republic. Geografický časopis, Vol. 62, No. 4, p. 279-291.

KUNC, J., FRANTÁL, B., TONEV, P., SZCZYRBA, Z. (2012): Spatial patterns of daily and non-daily commuting for retail shopping: The case of the Brno City, Czech Republic. Moravian Geographical Reports, Vol. 20, No. 4, p. 39-54.

KVĚTOŇ, V., CHMELÍK, J., VONDRÁČKOVÁ, P., MARADA, M. (2012): Development in the public transport serviceability in rural settlements with examples from various types of micro-regions. AUC Geographica, Vol. 47, No. 1, p. 51-63.

LEINBACH, T. (2004): City Interactions: The dynamics of passenger and freight flows. In: Hanson, S., Giuliano, G. [eds.]: The Geography of Urban Transportation, The Guilford Press, New York, p. 31-58.

MARADA, M. (2008): Transport and geographic organization of society: Case study of Czechia. Geografie, Vol. 113, No. 3, p. 285-301.

MORRILL, R. L. (1974): The Spatial Organization of Society. Duxbury Press, North Scituate, 267 pp.

MULÍČEK, O., SÝKORA, L. (2011): Atlas sídelního systému České republiky. Ústav územního rozvoje, 72 pp.

MULLER, P. O. (2004): Transportation and Urban Form: Stages in the Spatial Evolution of the American Metropolis. In: Hanson, S., Giuliano, G. [eds.]: The Geography of Urban Transportation, The Guilford Press, New York, p. 59-87.
NUHN, H., HESSE, M. (2006): Verkehrsgeographie Grundriss, Allgemeine, Geographie. Paderborn, 379 pp.

NYUSTEN, J., DACEY, M. (1961): A Graph Theory Interpretation of Nodal Regions. Papers in Regional Science, Vol. 7, No. 1, p. 29-42.

Road Transport Census (2010): Road and Motorway Directorate of the Czech Republic [on-line], [cit. 06.09.2012]. Accessible at: Url: http://scitani2010.rsd.cz

RODRIGUE, J.-P., COMTOIS, C., SLACK, B. (2006): The Geography of Transport Systems, Routledge, New York, 296 pp.

ŘEHÁK, S. (1988): Možnosti dalšího rozvoje naší geografie dopravy. In: Holeček, M. [ed.]: Současný stav a perspektivy dopravní geografie, Geografický Ústav ČSAV, Brno, p. 15-20.

SHELLER, M., URRY, J. (2006): The new mobilities paradigm. Environment and Planning A, Vol. 38, p. 207-226.

SEIDENGLANZ, D. (2010): Transport relations among settlement centres in the eastern part of the Czech Republic as a potential for polycentricity. Acta Universitatis Carolinae - Geographica, Praha, No. 1, p. 75-89.

SÝKORA, L., MULÍČEK, O. (2009): The micro-regional nature of functional urban areas (FUAs): lessons from the analysis of Czech urban and regional system. Urban Research and Practice, 2, p. 287-307.

ŠLAMPA, O. (1972): K pojetí a způsobu vymezování dopravních oblastí. Scripta Fac. Sci. Nat. UJEP Brunnensis, Geographica No. 1-2, Brno, p. 19-28.

TOUŠEK, V., BAŠTOVÁ, M., KREJČÍ, T., TONEV, P. (2005): Změny $\mathrm{v}$ dojížd’ce za prací do českých velkoměst v letech 1991-2001. In: Zmeny v štruktúre krajiny ako reflexia súčasných spoločenských zmien $\mathrm{v}$ strednej a východnej Európe. Košice, Univerzita P. J. Šafárika, p. 9-14.

ULLMAN, E. (1980): Geography as Spatial Interaction. University of Washington Press, Seattle, $231 \mathrm{p}$.

URBÁNKOVÁ, J., OUŘEDNÍČEK, M. (2006): Vliv suburbanizace na dopravu v Pražském městském regionu. In: Ouředníček, M. [ed.]: Sociální geografie Pražského městského regionu. PřF UK, Praha, p. 79-95.

WHEELER, J., MULLER, P. (1986): Economic Geography. Wiley, New York, 412 pp.

\section{Authors addresses:}

RNDr. Stanislav KRAFT, Ph.D., e-mail: kraft@pf.jcu.cz Mgr. Michal VANČURA, Ph.D., e-mail: vancura@pf.jcu.cz Department of Geography, Faculty of Education, University of South Bohemia in České Budějovice Jeronýmova 10, 37115 České Budějovice, Czech Republic

Assoc. Prof. RNDr. Marián HALÁS, Ph.D., e-mail: marian.halas@upol.cz Department of Geography, Faculty of Science, Palacký University in Olomouc 17. listopadu 12, 77146 Olomouc, Czech Republic

Initial submission 10 June 2013, final acceptance 16 February 2014

KRAFT, S., HALÁS, M., VANČURA, M. (2014): The delimitation of urban hinterlands based on transport flows: A case study of regional capitals in the Czech Republic. Moravian Geographical Reports, Vol. 22, No. 1, p. 24-32. DOI: 10.2478/mgr-2014-0003. 